\title{
On Not Excluding Half of the Human in Human Geography: interview with Janice Monk
}

\author{
Joseli Maria Silva \\ Universidade Estadual de Ponta Grossa \\ joseli.genero@gmail.com
}

In March 2010 the first issue of Latin American Journal of Geography and Gender was launched, when Janice Jones Monk, one of the most important contributors to the development of gender perspective in geographical science, turned seventy three years old. Janice Monk was born on March 13th 1937 in Sydney, Australia, but she has lived most of her life in the United States, where for more than fifty years she has devoted herself to the production of geographical knowledge, almost entirely based on feminist perspectives. Janice Monk got her doctorate degree in Geography at the University of Illinois in 1972, at the time of strong expansion of feminist thought in the United States.

The extension of her professional experience and her contribution to the development of geographic thought, especially for gender studies, is immeasurable. Janice Monk is currently Research Social Scientist Emerita Women's Studies, Professor of the School of Geography and Development, University of Arizona and Senior Fellow of the Association of American Geographers. Besides acting intensively in the academic field, she actively participates in institutions like the National Council for
Geographic Education, National Council for Research on Women, Society of Woman Geographers, the International Geographical Union and also the Association of American Geographers which she served as President in 20012002.

Exploring the life of this eminent geographer, whose life is associated with the history of feminist thought in Geography, is a great opportunity to express a female version of our scientific history, full of male names. Besides presenting different versions of hegemonic thougtht, this interview is intended to be an inspiration for the construction of a feminist geographical thought in Latin America.

The interview is structured in three segments that are related to each other and reflect the features of Janice Monk's scientific production. The first one is related to making visible social minority social groups in Geography, such as women, from the feminist perspective. The second one is based in the process of feminist geographical thought development. The third one directs the interview to the production of a Feminist Geography, based in alliances between different parts of the world. 
Joseli Maria Silva: The beginning of the battle for women's visibility and the criticism of the masculine character of Geography are expressed in the article 'On Not Excluding Half of the Human in Human Geography' published in 1982 with Susan Hanson in The Professional Geographer. What was the impact of these ideas in academic field at the time of this publication?

Janice Monk: When Susan and I wrote this article, we were aiming to contribute not only to the emerging field of the geographies of women but to question the 'mainstream' of the discipline, its purposes, theories, and methods of doing research. We wanted to reach broad audiences, not only those who were pioneering in addressing women's lives. In the years since, we have seen the article referred to as arguably the most significant early article in what has since become known as 'Feminist Geography' (JONES, NAST, and ROBERTS, 1997, p. xxi), yet initial reactions from feminist geographers who published commentaries on it suggested that did not grasp our intention. It was identified with a 'stage model' of 'add women and stir', critiqued for not going far enough, or for not taking up differences between socialist, radical, and liberal feminist perspectives. Interestingly, the interpretation of the paper as representing a 'stage' which simply advocated the addition of women has persisted in some feminist overviews of the historical development of the field. Yet we also find examples of geographers not primarily engaged with gender studies who did understand our purposea and modfified their work, for example, in migration studies, to 'not exclude half the world'. Susan and I have explored the various ways the article was received by examining citations of it in the intervening years (HANSON and MONK, 2008.) In that reflection, we note that while Anglophone Feminist Geography and our own work has evolved, particularly with increasing attention to issues of subjectivity and identity, we still retain our goals of advancing non-sexist and inclusive practices in our work and lives.

JMS: Your article 'Many Roads: The Personal and Professional Lives of Women Geographers' explores the life course of women geographers, linking private/ personal and professional life in public spaces. At the beginning of the article 'When in the World Are Women' there is also a biographical rescue. Is this feature proper to feminist field? What are the reasons for the use of such approach? What is its influence in the research results?

JM: Introduction of the links between personal and professional life in the chapter 'Many Roads' was prompted partly by work I have been doing since the late 1980s on how the academy and careers are shaped by larger social and political cultures as well as by personal experiences. While the latter has been expressed in writing that advocated attention to 'positionality' (both of the researcher and those being researched) and 'reflexivity' on the part of the researcher to consider how her/his viewpoints are shaping interactions in the field, my aims have also been to show that our geographic work has to be contextualized in its places and times. In the piece to which you refer, 'When in the World are Women?' which first appeared in the book Full Circles: Geographies of Women over the Life Course (1993) Cindi Katz and I wanted to write an introduction that would illustrate both how place and time were important in women's lives and alert readers to ideas then not being explored in feminist geography. We also thoiugh it would make interesting reading if we used autobiographical 'stories', mine focusing on time - the spatial worlds of four generations of women in my own family - and Cindi's on comparative examples of place - how her age/stage in life differed from that of the girls and women in Sudan where she had conducted field research. We also thought that at the time, much feminist research assumed that the field was concerned with the lives of women in their reproductive/midlife years, and we wanted to expand that view. In the year since, geographic work on children and youth, a rarity well into the 1990s, has expanded considerably, so that there is now a specialized journal, Children's Geographies. Geographic research on later life has received less attention, though is beginning to grow, especially in parts of the world such as western Europe, where demographic aging is becoming more pronounced. A recent handbook reviewing directions in Social Geography includes a chapter age and ageism that introduces life course perspectives (a concept that attends to transitions, not simply distinct stages) and refers briefly to our book Full Circles (Pain and Hopkins, 2010) but this is after a gap of almost two decades since we wrote.

JMS: The article 'Practically All the Geographers Were Women' highlights the role of women in various spaces in Geography, at the same time as it makes visible the difficulties faced by these pioneer women. Did the growing feminization of science bring epistemological and methodological changes in the production of the geographic thought?

JM: The answer to this might best be 'no and yes'. In my article 'Women, Gender, and the Histories of American Geography' (2004), I aim to show how social and political histories, as well as the histories of higher education, have historically placed women in different places from men within the discipline. From the late 19th century to the mid-twentieth century in the US, for example, much education of teachers was carried out in what were initially called 'normal schools'. They offered courses of two-years in duration. Later these institutions became known as 'state teachers colleges' (with four year degrees), and subsequently as state 
universities. As these transitions occurred, the functions of the institutions changed from primarily preparing teachers for schools to broader curricula. In their early years, many of the geographers in the normal schools were women, since teaching was identified as a profession for middle-class women. At the time, there was little Geography taught in the universities, but as universities grew they favored hiring ('bright, young') men not (mid-life) women. Many of the women in the early teachers colleges were professionally very active however, and held positions of leadership in the National Council of Geography Teachers (later National Council for Geographic Education). They published, especially in the Journal of Geography (focusing on education) and wrote textbooks. Some travelled widely, nationally and internationally and did field research. Some of their publications reveal attention to girls as well as boys, and to issues of diversity (for example, by ethnicity or awareness of immigrant children). But they also worked within the larger paradigms of their era and in that were not distinctively presenting feminist views. During World War II, another professional change, though often temporary, occurred as many women were recruited into federal government agencies for such tasks as mapping. Conversely, the 1950s and 1960s were lower points in the representation and visibility of women in Geography, marked as post-war US society was by a coservative culture of home and family, The earlier generations of women geographers were retiring, yet universities were growing; men were mainly those hired, the proportions of women among geographers decreased, and the scientific thinking of the period focused on new positivist and quantitative directions into which those few geographers practicing were socialized. Then the feminist movements that flowered in society beginning in the 1970s saw a new generation of women seeking professional lives, and they were influenced by the new consciousness which they brought to their work as they sought (and often struggled) for positions in universities. It was this group of women that fostered feminist perspectives in research and teaching. The same period saw the development of feminist scholarship across disciplines and the introduction of women's studies (later gender studies) programs in American universities, so that women in Geography had a larger academic community of reference. There were additional political currents, but it is beyond the scope of this interview to elaborate on those. But my larger point is that trends in thinking are not independent of prevailing paradigms, power structures, and larger social forces.

JMS: After many decades of feminist perspective advancement in Geography, what are, In your opinion, the main contributions of this perspective for geographical science as a whole?

JM: As I see it, the main contributions have been to prompt more attention topically to multiple aspects of diversity - not only gender but also race, ethnicity, sexuality, and youth. Additionally, feminist scholarship has been central in fostering attention to qualitative methods, and to philosophical and methodolgical issues such as aspects of subjectivity, 'reflexivity', 'positionality', the intersections of identities, and aspects of life such as emotions that are intertwined with experiences of and shaping of spaces and places. These ideas now permeate multiple areas of Human (Cultural, Social) Geography, not only work in which gender is central.

JMS: The Feminist Geographies have developed in different theoretical and methodological paths that, in same way, still live together. Today, what are the contributions of post-structuralism, post-colonialism and queer perspective to the field of Feminist Geography?

JM: My answer to this question would repeat much of what I wrote with respect to the previous one --- greater concerns with the complexities of difference, diversity, subjectivity, and the body, as well as to thinking of knowledge as socially, culturally and politically constructed, and as intertwined with power relations.

JMS: In your research history, expressed in several scientific papers, highlights a concern with the prospect of 'other' and partnerships with academic researchers outside the Anglo-Saxon academic field. This practice, however, is not a common feature of Feminist Geography, which is strongly enclosed within English-speaking countries. Why this trend, that works contesting discursive authorities, paradoxically, has not expanded alliances between researchers from countries with adverse economic and cultural contexts?

JM: Partly it is because of the dominance of English language and the lack of multi-lingualism among native speakers of English. Partly it is the neoliberal political pressures for Anglophone academics to publish often and rapidly, and to focus on theories at the expense of some of the time-consuming aspects of learning other languages and doing sustained empirical work. Partly it is the change in publishing practices, with the related expansion of commerical presses in the Anglophone world taking on academic journals that used to be published by scholarly societies and universities, and the culture of ranking the prestige of these journals. Such academic politics discourage Anglophone scholars from publishing in other languages (even if they are competent in them) or of reaching out beyond their national (or the British-US) systems to publish in journals commonly outside the ranking system. There are some ironies in this situation - Anglophone human geographers have drawn much of their theoretical orientations from continental Europe (for example, from French philosophers), even as geographers in 
some traditions outside the Anglophone may adhere more to positivist, empirical, and applied studies. Since I have long enjoyed and engaged with geographers from beyond my local milieu, I regret these other tendencies, but also reflect on why I have chosen my path. To some extent, I attribute it to having grown up in Australia, outside the British-American 'heartlands', in a lower income family in a place and time where non-British immigrants were arriving in substantial numbers and we became aware of the 'other'. Also it was a time and place of being in an educational system that was making resources available for youth who might otherwise have lacked opportunities. Additionally, young Australians, especially women, seeing ourselves on the peripheries and not ready yet to settle in being wives and mothers, were attuned to international travel, of 'going overseas' (even if temporarily). By comparison, young men were more likely to remain at home for their careers. Because my father also had interests in other parts of the world, though not the resources to travel abroad, I grew up with awareness of the non-local. So we come back to the intersections of gender, class, what education offers and rewards, and of place and time.

JMS: What relationships can be established between the theoretical increment of Feminist Geography and social practices? What is the role of academic research in social changes?

JM: This is a matter I ponder and of some concern. I think we need theories, but we also need to see what difference they can make in society and to collaborate and communicate beyond academia and the national. Here I have been pleased to see the growing interest in and commitment to participatory action research, an approach which feminist geographers have played a significant role in fostering in Anglophone Geography. In the 25 years I was employed at the Southwest Institute for Research on Women at the University of Arizona, we always engaged with projects that not only produced books and articles, but that also worked with teachers, students, and community groups in educational projects, in arenas such as health, economics, literature and the arts, and in science education for girls. We collaborated with colleagues in northern Mexico reflecting our location close to the international border and saw the distinctive heritage of our region (American Indian, Mexican American, and Anglo American) as central to our projects.. I believe that such collaborations and multi-faceted perspectives are important for academic research, teaching, and community work.

JMS: The article 'Place Matters: Comparative International Perspectives on Feminist Geography' analyzes the spatial variations of the development of Feminist Geography in different countries, considering different cultural contexts that influence this subject. How can cooperation between different countries be increased to promote and disseminate knowledge freely in a social reality in which it has become a commodity?

JM: As geographers who think that place matters, it is perhaps inevitable that where we are shapes our ways of looking at the world. But we are also increasingly aware as geographers of the implication of globalization in economies in new ways (not only the legacies of colonialisms) through technology, migration, business practices and so on, and of the global environmental challenges. Thus I see it as increasingly important that geographers, including feminist geographers, work to foster understandings that cross national, cultural, and linguistic border. It takes time, commitment, and resources that may run counter to the rewards offered by our local systems, but I see it as both rewarding as well as essential.

\section{Referências}

JONES III, John Paul, NAST, Heidi J., ROBERTS, Susan M.. Thresholds in Feminist Geography: difference, methodology, representation. Lanhan, Md. And Oxford: Rowman \& Littlefield Publishers, 1997.

MONK, Janice, HANSON, Susan.”On Not Excluding Half of the Human in Human Geography" . The Professional Geographer, v. 34, n 1, p. 11-23, 1982.

MONK, Janice, KATZ, Cindi. "When in the World are Women?”. In: KATZ, Cindi, MONK, Janice. Full Circles: Geographies of Women Over Life Course. London: Routledge, 1993. p. 1-26.

MONK, Janice. "Place Matters: Comparative International Perspectives on Feminist Geography". The Professional Geographer, v. 46, n. 3, p. 277- 288, 1994.

MONK, Janice. "Many Roads: The Personal and Professional Lives of Women Geographers." In: MOSS, Pamela. Placing Autobiography in Geography. Syracuse: Syracuse University Press, 2001. p. 167-187.

MONK, Janice. Women, Gender, and the Histories of American Geography. Annals of the Association of American Geographers, v. 94, n. 1, p. 1-22, 2004,.

MONK, Janice, HANSON, Susan. "On Not Excluding Half of the Human in Human Geography" . In: OAKES, Timothy, PRICE, Patricia L. The Cultural Geography Reader. New York: Routledge, 2008.

p. $365-372$

MONK, Janice, KATZ, Cindi. "When in the World are Women?”. In: BAUDER, Harald, ENGEL DI-MAURO, Salvatore. Critical Geographies: A Collection of Readings. Kelowna-Canadá: Praxis-epress, 2008. Disponível em: $<$ http://www.praxis-epress.org/CGR/17-Monk_and_Katz. pdf . Acesso em 30/03/2010. p. 218-40.

MONK, Janice. Practically All the Geographers Were Women. Presentation at Society of Woman Geographers Triennial, 2008. Disponível em: <http://www.iswg.org/ about1.html>. Acesso em 01/04/2010. 